\title{
The Terrible Embrace of the Incipient Baroque: Textually Enacting the Union of Crowns
}

\author{
John Slater \\ University of California, Davis
}

\begin{abstract}
Portugal and Spain were ruled by a single monarchy from 1580 to 1640; the images of encircling and embracing that accompanied Castilian celebrations of the Union of Crowns indicate that new language accompanied the new political reality. This new language became the idiom of an incipient baroque, a regime of representation that rendered perceptible the particular aspirations of a universal monarchy. Through successive Castilian translations and adaptations, seminal Portuguese works crisscrossed the Hapsburg empire, enclosing the globe in a textual embrace. Textual enclosure became one of the means by which the Hapsburg empire was enacted.
\end{abstract}

Keywords: baroque, Union of Crowns, Moluccas and Banda Islands, Garcia de Orta, João de Barros, Laurel de Apolo.

The Iberian Union (1580-1640) put an end to the contentious issue of control over the spice trade in the Moluccas and Banda Islands of the Pacific, a matter that "preoccupied European diplomacy" for decades during the sixteenth century (Brotton 121). As Ricardo Padrón neatly summarizes, "upon the arrival of Magellan's ships in the Spice Islands, Castile's westward expansion across half the world met up with Portugal's eastward drive across the other half" ("A Sea of Denial" 11). In seventeenth-century Spain, however, this meeting point of imperial enterprises-where Castilian "expansion" met Portuguese "drive"was more often represented as fingers interlocking at the terminus of a global embrace than a point at which legal and territorial claims came into conflict. 
As the images of encircling and embracing suggest, the Union of Crowns, and the resolution of the "Moluccas Question," provided new language and iconography to represent potentially global empire. This new language became the idiom of an incipient baroque, a regime of representation that demonstrated an awareness of and was alloyed to the particular aspirations of a universal monarchy.

The baroque fascination with seeming (rather than being), its facile interest in the exotic and bizarre, its vulgar exuberance and lack of restraint, and its scandalous way of making itself at home in many times and places, make it an aesthetic pharmakon: simultaneously enthralling and embarrassing. ${ }^{1}$ As the art of bad faith-of merely seeming, and of unseemly proliferation-one of the achieved political expressions of the incipient baroque is the Iberian Union. Of course, this is only one of many points of origin of the baroque, albeit a significant one. Textual representations of the Spice Islands, the metropolitan antipode, provide a particularly clear window to the generation of the early modern baroque in Iberia. It may be the case that the baroque "inevitably embraces hybridity" (Davidson 12); however, there was sometimes claustrophobia in the inevitability of this embrace. Early modern Spain itself, as a kind of imperial dream, was a political allegory of the baroque: bits and kingdoms were drawn together, and the result was a sparkling nonplus.

The history of the Spice Islands under dynastic union has been the subject of excellent works over the last few decades, by scholars such as Consuelo Varela, Mafalda Soares da Cunha, Manuel Lobato, Florbela Veiga Frade, Leonard Y. Andaya, and others. However, the historical events occurring in the Pacific were often uncoupled from the symbolic programs designed to communicate the transcendent significance of dynastic union. Understanding the function and importance of early modern accounts of the Spice Islands often involves paying attention to the information that is stricken, the unhistorical bits and pieces that are added, and all manner of additions and elisions that shape texts as they are translated, copied, paraphrased, and versified. Rather than contributing to the history of the Spice Islands, an examination of the meaning of the Moluccas and Banda Islands during the Union of Crowns casts light upon Iberian imperial aspirations and the ways in which these aspirations were represented. In following the protean afterlives of texts by authors such 
as Garcia de Orta and João de Barros, two things become apparent. First, the translation and dissemination of texts are not simply epiphenomena of empire; instead the global movement of texts is one of the means by which the Spanish Hapsburgs enacted their empire. Second, the meeting of politics and representation in the context of the Union of Crowns presages a number of characteristics of an enduring and global baroque; an incipient Iberian baroque is born in the terrible embrace of a global empire.

Dynastic union was accompanied by a fusion of historical accounts-a way of understanding providential history and navigational history as essentially the same-and created new trajectories for the movement of texts. In The Universal Baroque, Peter Davidson describes the early modern baroque as a roiled confluence of confessional, representational, and political aspirations. Davidson's ruminations on the universality of the baroque are particularly helpful for understanding the incipient baroque. The "enemy of the Baroque," as Davidson defines it, "is the nation-state." The incipient baroque is a means of deploying baroque tools to envision a universal monarchy that supersedes the nation-state. Davidson continues: "The Jesuits, enemies of the nation-state themselves, were among the chief proponents of the baroque arts" (9). To be sure, the encyclopedic dream of global governance that accompanied the Iberian Union was not the enemy of the nation-state in the same way that the nationstate might be the enemy of the baroque. However, Spanish imperial discourses during the Iberian Union-including works written by Jesuits-conflated the symbolism of divine providence and the human achievements of circumnavigation so as to rebuff the claims of any particular nation-state, save one.

In 1580, the creation of a global empire involved the aggregation of Portugal to the Hapsburg monarchy; in parallel fashion, the creation of new imperial discourses often involved the appropriation, adaptation and translation of Portuguese texts. Luís de Camões' Os Lusíadas itself was translated into Castilian in 1580. Thus, the universality of the baroque received an early impulse in the Union of Crowns; mixing genres, crossing linguistic borders, and gathering traces of long journeys across oceans and time, were some of the initial tendencies of the early modern baroque. It was not circumstantial that these textual crossings mirrored the political belief that Hapsburg power knew no natural boundaries. 
Global monarchy found its emblem and conceptual center in the Spice Islands. These islands were the source of considerable cartographic consternation because somewhere in their vicinity a line of demarcation was to divide the half of the globe that pertained to Spain from that belonging to Portugal. In determining the location of this dividing line or half-meridian, something not addressed in the Treaty of Tordesillas, control of the trade in cloves, pepper, mace and nutmeg was at stake. The half-meridian was subject to controversy, underhanded manipulation, and negotiation. There were clarifications and rectifications from the Papacy, the leasing of the Spice Islands to Portugal by Carlos V of Spain in 1529, and the espionage and subterfuge that constitute one of the more exciting moments in the history of early modern science (Goodman 61-2). As María Portuondo points out, Magellan discovered these islands once in 1511 "on behalf of the Portuguese," and "then deftly reclaimed them in favor of Spain in 1521" (67). The Moluccas and Banda Islands seemed to drift between Spanish and Portuguese possession, like the floating island of Aeolia.

In some ways, "the conflict over the possession of the Moluccas" was a proxy for old tensions; Kevin Sheehan calls it "a manifestation of an ongoing series of political and economic rivalries and territorial disputes traceable to the end of the Middle Ages" (3). In other ways, the "Moluccas Question" reflected a broader debate about the cultural reach of the Portuguese and Spanish empires, a debate that engaged linguistic, terminological, mercantile, and literary issues, as well as cartographic ones. Much like a line of demarcation established by treaty, the distinction between what was properly Spanish and Portuguese could be strategically blurred.

This blurring is easily detectable in the freighted linguistic politics of Portuguese authors writing in Spanish under Hapsburg rule. Portuguese authors often made a point of explaining the near ubiquity of the Spanish language in terms that were more or less flattering to the Crown. ${ }^{2}$ In 1624, Luís Coelho de Barbuda excused himself for writing his "narraciones" of the Reyes de Portugal in Spanish, by arguing in the prefatory address to his readers that because Portuguese was not widely spoken, the accomplishments of Portugal's monarchs were not widely known. Five years later, Pedro Homem Barbosa included a biting prologue or apologia dedicated to explaining his rather reluctant decision 
to write in the Spanish vernacular instead of his native Portuguese; as he puts it, the Portuguese language might be better than foreign languages but it was understood and spoken by very few people. This apologia may have been highly conventional-many texts written in the vernacular, rather than Latin, contained similar defenses-but it would prove to be influential. Just two years later, António de Sousa de Macedo defended his own decision to write Flores de España, excelencias de Portugal in Spanish by building on Barbosa's earlier argument. Dulling Barbosa's irony, but reproducing his reasons, Macedo begs the reader's pardon for abandoning Portuguese explaining that Spanish was simply more "universal."

The fact that Macedo imagines degrees of universality-as if Hapsburg power could be more or less omnipresent-underscores the strained rhetorical concessions of these works. Barbuda, Barbosa, and Macedo, however, also helped forge the image of Spain's rule as global. In a sense, Portuguese writers during the Iberian Union sought to defend Portugal's legitimacy through claims of Spanish universality. Barbuda, Barbosa, and Macedo wrote Portuguese exemplarity into the story of Spanish global supremacy. Castilian culture and language would be the means by which Barbuda made Portuguese monarchs models for kingship, by which Barbosa's descriptions of João II would become a mirror for princes, and Macedo's title-Flores de España, excelencias de Portugal-might, for Castilian readers, portray Portuguese excellences as rooted in Spain, even if this argument was understood differently in Portugal. The kingdoms of Portugal and Castile remained intact, but the monarchy was, to borrow Macedo's word, universal.

Not surprisingly, the Moluccas and Banda Islands, imagined as the geographic limit of each empire's reach, played an important role in the discourse of global rule. ${ }^{4}$ The very indeterminacy of the half-meridian opened up rhetorical spaces to understand how particular claims to territorial or cultural supremacy might be erased. Blurring, erasure, and elision were as often as not symptoms of Castilian anxiety, as well as ambition; as Rafael Valladares explains, both Castilians and Portuguese feared their efforts in the Pacific would be "absorbed" by the other (Castilla y Portugal 107-8). The answer to the problems concerning the possession and the identity of the Spice Islands did 
not involve more exacting maps, but more encompassing language. This language would render the half-meridian simply conventional rather than cartographic, and would place the meeting of Castile and Portugal in the Moluccas within the realm of providential history, not navigational happenstance.

Fernando Bouza has pieced together the complicated heraldic and iconographic negotiations that ensued upon Felipe II's accession to the Portuguese throne (Imagen 68-89). Bouza explains that the achievement of Felipe's universal lordship (señorío universal) was symbolized in an emblem depicting two hands-a right hand and a left, interlocking fingers-with the motto "Ex concordia plenitudo imperii." Peace, it was hoped, would lead to the fullness of imperial power (Bouza, Imagen 74-75). This was not, the thinking went, new; it was in fact a restoration of Spanish monarchy through the inclusion of Portugal (Bouza, Imagen 75). The idea that the empires of Spain and Portugal could be conceived as two hands governed by a single head of state would become an important image of Spain's Pacific dominion.

The moment when Castile and Portugal "met up," in Padrón's terms, or "linked up," in Charles R. Boxer's, had enduring symbolic power (Boxer, The Portuguese Seaborne Empire 2). Boxer, for example, explained that global embrace "first made Humanity conscious, however dimly, of its essential unity" (2). We still tend to imagine the empire as a chain: Valladares calls "Portugal hispánico" the "thickest link in a chain that was broken only with great effort" ("Portugal hispánico" 10). The power of this moment in the human imagination is probably attributable to Felipe II's careful management of image and message. The iconography of global embrace and rhetoric of encircling appropriated traditional symbols of divine providence. Francisco de la Torre y Sevil's translation of Nicolas Caussin's iconographic manual, Símbolos selectos y parábolas históricas (1677), explained that images such as the globe encircled with a chain (the end of which was usually held by the hand of God or manus Dei) symbolized that God's providence was everywhere (351). Seventeenthcentury Castilian uses of such symbols tended to fuse the encircling of Divine Providence to the language of circumnavigation. Sebastián del Cano's ship became a conquering bark-Leño vencedor - that was able to gird (ceñir) "todo el Globo de la tierra" (Sayas Rabanera 534). Writing from the epicenter of the 
Spanish metropolis, the Jesuit Imperial College, Juan Cortés Osorio explained that embracing the world, or "abrazando el universo," made the globe measurable and thus "comprensible."

By the time Francisco Colin published his Labor evangélica in 1663, the Moluccas' special place within providential history had become conventionalized. The Labor evangélica is "one of the most comprehensive studies of the work of the Jesuits in Asia," and Colin uses events in the Pacific to create a new chronology of divine intervention in the course of Spanish history (Andaya 19). The first significant date in this new calendar, according to Colin, is 1521, not 1492. Having sailed halfway around the world, "uno por el Oriente, y otro por el Occidente," the Spanish and Portuguese "se encontraron ... en las Islas Malucas" ("Al religioso lector"). For Colin, this was not the periphery of these empires; rather, it was the "centro de entrambas Indias Oriental y Occidental," the point at which the known world met the unknown ("Al religioso lector"). The miraculous year of 1521, notes Colin, also marked the conquest of Mexico. The order here is important, however; as Colin tells it, the conquest of Mexico is secondary in importance to the meeting of Spain and Portugal at the center of the Indies. ${ }^{5}$ Further evidence that the contrary eastern and western trajectories, ultimately resolved in the Moluccas, were for Colin the primary drama in this annus mirabilis is the fact that he presents the navigations of Spanish and Portuguese sailors as an explicit foreshadowing of the movement of Jesuits.

The third sign within Labor evangélica that 1521 was a year of great beginnings is that it was the year of Ignatius Loyola's conversion. Like the two great nations that preceded them, the Jesuits depart on a spiritual circumnavigation, "unos, la vuelta del Oriente, y otros del Occidente" ("Al religioso lector"). They meet in what only seems to be the "ends of the earth" but are actually the "principios del mar" ("Al religioso lector"). The Moluccas, as the beginning of the sea and center of the Indies, are for Colin the focal point of all subsequent historic achievement. As he puts it, the Jesuits move "al modo de los compañeros de Magallanes" and "se encontraron venturosamente en estos Archipielagos del Oriente" ("Al religioso lector"). In effect, Colin denotes a specific geographical location where the interlocking fingers of the emblem elucidated by Bouza meet. 
To this point, it is clear that the Moluccas in Colin's Labor evangélica are not a zone of conflict but rather a point at which military and evangelical missions gain universal significance. Sailors not only precede but also prefigure the georgic "labor" of Jesuit missionaries. Colin is quick to point out, however, that it is not Magellan alone who is a harbinger of Jesuit victories. The Moluccas are also the place where Old Testament prophecy is fulfilled. These are the islands foretold by Moses, Ezekiel, Jeremiah, and Isaiah, who spoke of the region repeatedly ("Al religioso lector"). In this way, Colin suggests that global historical narrative-a lens through which Magellan, Loyola, and even Biblical prophecy can be understood as collectively informing-truly begins in 1521. Colin finds in the extremities of empire a divine mystery to be pondered. The representations of the Spice Islands in this context can be compared to Josiah Blackmore's discussion of the representation of Africa in Os Lusíadas; whereas for Camões Africa was a "hiatus in forward movement" or a "suspended nautical movement," the Moluccas for Colin were the endpoint of expansion and the final destination of empire (xvi).

Within the Labor evangélica, the Moluccas function as a flattering mirror in which Castile might see the revelation of its imperial purpose and role in history. Any allusion to debates over the possession of the islands is entirely absent from Colin's language in these passages. This is not surprising, given the fact that by 1663 when the book was published the Guerra da Restauração (1640-1668) was nearly over; furthermore, control of the islands had been lost to the Dutch decades before. ${ }^{6}$ Possession was by this time a moot point.

During the Iberian Union, images of encircling no longer suggested simply that God's providence was everywhere; now the human agents of divinity made providential encircling a cartographic and historical reality. Encircling the world became simultaneously an emblem of providence and a story of imperial achievement. Circumnavigation and providential embrace also mirrored the movements of texts within the literary economy of the incipient baroque. Sixteenth-century Portuguese descriptions of the Pacific, whether written in the service of the Aviz dynasty or used as sources of information that might facilitate the objects of Portugal's empire, became during the Iberian Union the building blocks of a new discourse of Hapsburg imperial might. This 
journey into the Iberian baroque conceptually begins with the meeting of Castilian and Portuguese empires in the Pacific; in more concrete terms, however, it starts with the passage (translatio) of Portuguese texts into Spanish.

After an initial wave of descriptions of the Spice Islands by early sixteenthcentury authors such as Maximilian of Transylvania and Antonio Pigafetta, the formal and stylistic characteristics of these descriptions were conventionalized during the middle decades of the century by seminal authors such as Garcia de Orta, Fernão Lopes de Castanheda, João de Barros, and Gabriel Rebello, as well as in manuscripts such as the "Tratado de las Yslas de los Malucos," which may have been written by António Galvão. ${ }^{7}$ Leonard Y. Andaya explains that the conventions of Portuguese chronicles tended to be durable and were reproduced with "monotonous regularity" (144). Highly standardized Portuguese accounts were then borrowed, often verbatim, translated, used in histories, versified in lyric poems, dramatized in plays, and so on. Particular passages of Barros' description, for example, would be recognizable even after repeated translation and repackaging.

Tracing the fate of Orta's description of cloves (Syzygium aromaticum [L.]) over the period of a century (1563-1663) provides a representative example of the fates of conventionalized accounts of the nature and cultures of the Spice Islands. Orta's Colóquios dos simples e drogas da Índia (1563) was the most important natural history of Pacific flora to be published in a European vernacular during the sixteenth century. It markedly influenced later Spanishlanguage works such as Juan Fragoso’s Discursos de las cosas aromáticas (1572) and Cristóvão da Costa’s Tractado de las drogas, y medicinas de las Indias Orientales (1578). Costa's debts to Orta are well known (Costa admits as much), but even a glance at their texts confirms that Costa had the Colóquios at hand when writing his description of the clove. Orta writes: "Quando o cravo he verde fazem os que moram em Maluco conserva de vinagre e sal (a que chamam achar), e fazem os verdes em conserva de açucare ... e fazem as molheres Portuguezas que lá moram agua estilada dos cravos verdes, e he muyto cheirosa y muyto cordeal..." (365). Costa echoes this: "Del Clavo verde se haze conserva de azucar y tambien lo echan en vinagre y sal, para comer (a que ellos llaman Achar) estilase [sic] dellos una agua de buen olor..."(82). 
Costa notably elides the reference to "molheres Portugezas," which was typical of this kind of borrowing; the national or political significance of Pacific flora was almost always recast through strategic omission when passages such as Orta's were reused. The process of reframing the political discourses inherent in early modern naturalist texts took a dramatic turn when Carolus Clusius translated Costa's text into Latin.

Clusius was often skeptical of Spanish-language texts, and he takes particular exception to Costa's description of the clove. As Brian Ogilvie notes, Costa's description and illustration "immediately attracted Clusius' scorn" (247). Clusius compares Costa's text not only to "the branches from clove trees brought to Antwerp by merchants," but also to a branch brought "to London by [Francis] Drake" (248). For Ogilvie, this is a rather straightforward comparison of a natural original to Costa's text; to an Iberian naturalist, however, the invocation of Drake-routinely referred to as the Antichrist-would have been scandalous. Colin, in fact, doubts that Clusius has ever actually seen a branch of the Syzygium aromaticum, stating that there is no one in the Spanish Philippines ("Y por acá, no hay quien dé fe...") who can actually attest to having seen anything matching Clusius' description (113).

Between 1563 and 1663, a single description of the clove travelled from Goa, where Orta wrote in Portuguese, to Burgos, where Costa wrote in Spanish, to Antwerp, where Clusius wrote in Latin, to Colin’s Spanish "acá," the particular vantage point of the Spanish Philippines. Along the way, this bit of text gained and lost political meanings; it became a locus for contesting systems of authority and political legitimacy. The "molheres Portugezas" disappear, Francis Drake makes a typically dramatic entrance, and all the while the description of cloves remains identifiable as Orta's creation. These transoceanic travels, as well as the accretion and loss of particular political meanings, would become hallmarks of the baroque.

It is tempting to think of works by naturalists such as Orta as celebrations of Portugal's trading successes; the Castilian appropriation of naturalists' texts might then, very neatly, be envisioned as a symbolic appropriation of Portugal's trade with the Pacific. Boxer, however, cautions that the crown "did not ultimately derive much profit" from trade in the Spice Islands (The 
Portuguese Seaborne Empire 61). So the relationship among knowledge, trade, and power is more complicated than it might seem. Representing cloves and nutmeg as the emblematic fruits of global embrace involved a peculiar kind of Virgilian economic program, in which the horrors of war were rejected in favor of the attractions of greed. This is not to say that greed was ever praised or advocated; indeed, early modern writers and politicians were well aware of the "interaction between war and trade" (Boxer, "War and Trade" 3). Trade and greed had to be addressed obliquely; for example, in Lope de Vega's use of Barros' description of the Banda Islands, people are reduced to integers that determine their own value.

Barros' Década terceira (1563) sets out the four basic elements that become conventions, almost commonplaces, in descriptions of the Banda Islands during the sixteenth century: naming the islands; comparing the flora of Banda to European trees and flowers; stressing the seeming artifice or gardenlike qualities of the landscape; and describing the birds ("papagayos") that are attracted to the nutmeg and mace. Barros names the "cinco ilhas," compares the trees to a "pereira," compares the landscape to a "jardim" and a "pintura," and describes the "muitos papagayos \& pássaros diversos" (131). This description would ultimately make an appearance in a poem by Lope de Vega. Lope may have been familiar with a manuscript of Manuel de Faria e Sousa's posthumously published three-volume Asia portuguesa, a translation of Barros' Décadas, as the former had written an enthusiastic "Elogio al comentador" to Faria e Sousa's commentary on Camões' Os Lusíadas. Although Barros’ Décadas were copied and incorporated into texts nearly verbatim (almost always with the four commonplaces mentioned above), Faria e Sousa's translation of Barros' description of the Banda Islands profoundly alters the original (383). In fact, it is far more likely that the version of Barros' description that ultimately influenced Lope de Vega was translated from Portuguese into Italian and then into Spanish. It becomes apparent, in fact, that Lope de Vega uses a marvelously corrupted iteration of Barros' description to make the Banda Islands a Parnassian antipode of Spanish poetic greatness in the Laurel de Apolo (1630). It turns out to be a rather complicated journey from Barros to Lope; the first leg runs from Portugal to Italy. 
Working in Venice during the 1560s, Alfonso Ulloa quickly translated the first two volumes of the Décadas into Italian. Lach and Van Kley explain that Ulloa's efforts were only one measure of Barros' popularity throughout Europe (I: 191). ${ }^{8}$ Curiously, Ulloa does not translate the Década terceira that includes the description of Banda (Boxer, João de Barros 138). However, the fact that he uses Barros' works in an attempt, as Lucia Binotti explains, to reframe the linguistic and cultural relationships between Iberia and Italy suggests the power that the Décadas acquired almost immediately after publication.

The influence of the Décadas was such that they may have been a model for Giovanni Botero (Boxer, João de Barros 130). Botero's Relazioni universali (Universal relations), was a work of descriptive geography written in Italian, the first part of which was published in 1591. Botero is known to most readers for his Delle cause della grandezza e magnificenza delle città (On the causes of the greatness of cities, 1588) and Della ragione di stato (On the reason of state, 1589), but it would be the Relazioni that gave "the greatest currency to the author in his own time" (Headley 1134). There were two major Spanish translations of Botero's Relazioni, one by Diego Aguilar (1599 and 1603), and the other, less well known today, by Jaume Rebullosa, entitled Descripción de todas las provincias y reinos del mundo (Barcelona 1603, Barcelona 1610, and Girona 1622). Rebullosa published a number of works, but he made something of an industry repackaging Botero's writings in books such as Theatro de los mayores principes del mundo (1605), and the Historia eclesiástica y estado presente de la religión en todos los reynos de Europa, Asia, y Africa (1608). ${ }^{9}$ In the Descripción, Rebullosa faithfully translates Botero's borrowing of Barros' description of the Banda Islands.

Rebullosa's version of Barros' text subsequently takes a curious turn. Based on a comparison of emendations to Botero's original, Rebullosa's orthography, and the circumstantial fact that Rebullosa signs an aprobación to Lope's Hermosura de Angélica (1602), it seems certain that Rebullosa's translation (rather than Aguilar's) is the source for Lope de Vega's description of the Banda Islands in a poem entitled the Laurel de Apolo. In other words, Lope de Vega versifies Rebullosa's translation of Botero's copying of Barros' original. ${ }^{10}$ At this point, it will be necessary to work backward from Lope's Laurel toward Barros (via Botero) in order to make sense of the trajectory. 
The Laurel was a poem of nearly seven thousand verses, celebrating the greatness of nearly 300 Spanish poets. The third silva devotes over 160 verses to Portuguese poets and authors, notably Camões (III:72-97). The Laurel is a classic of poetic translatio, in which the heights of Parnassus and the most refined excellences in poetry have passed to Spain. ${ }^{11}$ Within Lope's poem, Portugal is merely one of many Spanish kingdoms and one of the longest geographic descriptions is of the Spice Islands. The Laurel, however, is not simply populated with Portuguese names, it also draws in significant ways on Portuguese models.

In the ninth silva of the poem, Lope sardonically compares novice poets who stream to Apollo's feet to birds flocking to the Banda Islands in pursuit of mace and nutmeg (IX: 501-536). The poets are undifferentiated zeroes ("ceros") whose value will be determined by their relationship to Apollo. The god is a whole number ("número guarismo"). If poets place themselves before the god they will be worth little, like a zero before a whole number, or 01; if they follow the god, they will be worth much more: 10. The relevant passage begins simply, naming the five islands that make up the archipelago where the spices can be found: "Banda / Neira, Rosolarguín, Guanape y Mira" (IX: 501-502). Almost immediately, Lope abandons his ironic portrayal of poets, and loses himself in rapt contemplation of the islands' natural history; he describes the fragrance of the trees in flower and the marvelous spectacle of parti-colored birds and blossoms mingling in the islands. The image of poets rushing to the feet of Apollo just as colorful birds flock to the fruits of exotic trees is not so different than one of the oldest metaphors for literary creation: bees collecting pollen. But the geographic specificity implies specific antecedents. Lope's passage is likely an allusion to Os Lusíadas; Camões mentions nutmeg and the Banda Islands explicitly in Canto X: "Olha de Banda as Ilhas, que se esmaltam / da vária cor que pinta o roxo fruto; / as aves variadas, que ali saltam, / da verde noz tomando seu tributo" (X, 133:1-4). Lope's passage is also a fairly literal versification of the description of islands taken from Rebullosa's translation of Botero's Relazioni.

Lope cited, alluded to, and versified passages from Botero's Relazioni frequently. In addition to the passage in the Laurel de Apolo, Padrón points out that Lope's Triunfo de la fe takes its description of Japan from Botero ("The Blood" 
522). The description of Constantinople in Lope's Novelas a Marcia Leonarda takes passages verbatim from the Relazioni (205-06). ${ }^{12}$ Lope mentions the Relazioni by name in a verse epistle (Obras poéticas 1243). And perhaps most significantly, Lope cites Botero as the source for his information about the Moluccas in a marginal note in the Jerusalén conquistada (236).

Although Padrón dismisses Lope's use of Botero as simple "cribbing" (522), A.K. Jameson's learned study of Lope's erudition warned decades ago that the poet's references were rarely transparent. In the case of the Laurel de Apolo, one might naturally puzzle at Lope's lengthy description of the Spice Islands in a poem dedicated to locating a new Helicon in Spain. But the nod to Camões and the versification of Botero serve a single end. Camões was by that time recognized as the great Iberian poet of empire and Os Lusíadas was one of the great narrative poems of the age, written to "resuscitate" and problematize "an imperialist zeal" (Blackmore xviii). Botero was the architect of a particular kind of geographic imagination, one that, in Headley's words, helped provide "the basis for a European imperialist universalism" (1136). Botero, although not unique in this respect, was especially persuasive in articulating "the implicit parallel between the late Roman imperial order and the present emerging global order" of the Spanish monarchy (Headley 1137). At the same time, Botero consistently linked "aesthetics and economics," ruminating on "the essential role of trade and art in the successful development of civil life" (Pardo 111). Osvaldo F. Pardo has shown that Botero's writings about commerce provided the "aesthetic and ideological matrix" for Bernardo de Balbuena's Grandeza mexicana, and much the same thing could be said about Botero's influence on the description of the Banda Islands in Lope's Laurel.

The logic of quantification (01 versus 10) that pervades the Banda episode invokes an economic context that pervades Os Lusíadas. In the Laurel, Lope couples Botero's vision of "imperialist universalism" and commerce with Camões' epic tale of Portuguese expansion to make trade into the model for a certain kind of poetic economy located in the Spice Islands. There is nothing particularly surprising about Lope's source texts; Botero's Relazioni often served as a key to unlock exotic literary references, and the complicated debts of early modern Castilian poets to Camões have demanded monographic study 
(Nicolopulous). ${ }^{13}$ What is telling about the Banda episode is Lope's suggestion that the Spice Islands were a figurative point of dispersal within the global economy of poetic dissemination. He accomplishes this by overlaying the Spanish Parnassus on a location associated with Portuguese trade and Camões' greatness.

Lope takes from Botero the four elements of the description that Barros had conventionalized. Lope, like Barros and Botero, names the islands, compares the blossoms of the "árbol macis" ('mace tree') to roses, places the entire scene within a framework of human artifice by comparing the prospect of the islands to what might be seen through triangular glasses, and describes the "papagayos" at some length. Blackmore explains that in Os Lusíadas, Camões "recapitulates, synthesizes, and poetically reconstrues the mainly prose historiographic tradition that is the poem's immediate textual antecessor" (xviii). Lope essentially performs a similar synthesis, but with descriptive geography standing in for history. ${ }^{14}$ By recapitulating the fundamental elements of previous descriptions of the Banda Islands, Lope exploits the non-cartographic, almost mythic qualities of Botero's descriptive geography, in which there are no topographical or natural limits placed on Spain's empire. In this way, Banda is not only a locus to understand the quantification of poetic value, it is also a site for the reproduction of geographic language, language that promises an "imperium without end" (Headley 1136).

By describing the Spanish Parnassus in terms of Portuguese geography, the Laurel rolls together a romance of imperial discursive greatness and a concern for gain and puts it in a specific place: either the limit of the Hapsburg monarchy's reach, or the origin of its empire, depending on one's perspective. Castilian writers used the Portuguese territories of the Moluccas and Banda islands to create an image of imperial Spain holding the world in a beneficent embrace; this was a Spain concerned with productivity, not conquest; inclusion, not destruction. Through the aggregation of Portugal, Spain came not simply to imagine the contours of far-off lands or the shape of distant seas but to envision the unbounded dimensions of the Hapsburg empire.

The baroque, as it developed in Castile and Portugal, tells the story of movements across frontiers and the accretion of influences and sources. I have traced two representative examples. The first follows Orta's cloves through Costa, on to Clusius, and finally to Colin. The second follows Barros' nutmeg 
through Botero to Rebullosa and then to Lope by way of Camões (and perhaps Morais Sardinha). These are, however, only two of many stories we might tell about the way the Moluccas and Banda Islands wove their way into accounts of Hapsburg imperial reach. Nearly all of the Portuguese descriptions of the Spice Islands written during the middle of the sixteenth century come to serve as prose models and poetic raw materials, moving in and out of languages, being published and republished in a variety of genres and formats.

From a modern perspective, the Spanish-language texts of Costa, Colin, Lope, and others, taken together may seem to constitute a troubling romance. Carmen Nocentelli, in her study of the "interracial plots" of Spanish plays set in the Moluccas, notes that these marriage stories "hid coercion under a veneer of contractual consent" (117). There are obvious differences to be drawn between the "interracial romances" examined by Nocentelli and the Union of Crowns; as in these plays, however, Spanish representations of Portuguese territories "celebrate expansion and mystify inequalities via a rhetoric of exchange and reciprocity" (Nocentelli 118). In the repeated references to measured and simultaneous eastward and westward itineraries, happy meetings, and an almost loving encircling, Portugal plays a vital, if subservient role, making possible a narrative of productive imperial equipoise.

The dynastic union of Spain and Portugal was both celebrated and condemned as a terrible realization of imperial ubiquity. Literary and historiographic attempts to come to terms with (theoretically) boundless monarchy hold a special place in the genesis of the early modern Iberian baroque. As Davidson has persuasively argued, the baroque is "universal" in the sense that it is "an agreed set of conventions overriding all the allegiances of religious confession or nationality" (1). In its earliest Iberian manifestations, however, the baroque was a "world-wide system" concerned with universality (Davidson 2). It was a means of representing that bore the signs of its own ubiquity: crossing linguistic borders, picking up pieces here and there, agglutinating references and places. Like a magpie, the Iberian baroque pilfers and caches baubles according to their luster. Texts such as Orta's and Barros' moved conceptually back and forth from the Spice Islands to the imperial capital, and traveled from one work to another, reproducing through legible traces the providential encircling of the Hapsburgs' global empire. 


\section{Notes}

1 As Peter Davidson contends, the baroque is a "cultural system so much in love with the remote and exotic that it draws strangeness unto itself, it is eager to explore and coexist with extremes, at the same time as it is a daily, serviceable set of conventions for discussing and celebrating quotidian experience" (12).

2 For a helpful overview of the linguistic and political issues at stake for Portuguese authors writing in Spanish, see Marcos de Dios, in addition to classic studies by García Peres, as well as Martínez Almoyna and Viera de Lemos.

3 Evidence that Macedo may have been influenced by Barbosa's apologia can be found in Macedo's description of the five qualities that contribute to the perfection of languages: abundance of words, ease of pronunciation, concision, clarity, and flexibility (236). The same list of five qualities appears in Barbosa's apologia.

4 Andaya points out that for the inhabitants of the Moluccas, the islands were a meeting place of "two worlds," but the meaning of this encounter was understood very differently (114-50).

5 The opinion that the discovery of America was overshadowed by events in the Pacific corresponds to what Valladares calls a "corriente orientalista" that had existed in Castile since the early Middle Ages ("Olivares y Oriente" 73).

6 The way we tell the story of the war that brought the Braganzas to the Portuguese throne is changing; see, for example, Fernando Dores Costa, as well as Valladares ("Portugal y el fin").

7 In addition to Andaya's comprehensive account of early European descriptions of the region-with particular attention to Pigafetta and Maximilian-see Gunn (21-22).

8 Binotti demonstrates that Ulloa's translations, masterpieces of "cultural miscegenation," were often politically charged (59). Binotti focuses on Ulloa's "program" to control and promote the canonicity of Spanish works in Italy (65). As the example of the Décadas indicates, however, Ulloa, like Camões, may have conceived broadly of "Spain."

9 Rebullosa's explanation of his decision to write in Spanish rather than Catalan recalls those of Portuguese authors: "Dexo de disculparte el lenguage con dezir que soy catalán, y que en mi vida [nunca] vi á Castilla" (Relación, "Prólogo al lector").

10 Lope describes the blossoms of the trees from which nutmeg and mace are harvested as similar to "rosas silvestres," or wild roses (Laurel 275), just as Rebullosa's translation of Botero does (Relaciones 373); the descriptions of the birds ("papagayos") and fragrance of the flowers are also nearly alike. On Botero and Lope, see Wright.

11 In its relocation of Parnassus to Iberia and its fascination with the Spice Islands, Lope's Laurel recalls Francisco de Morais Sardinha’s O parnaso de Vila Viçosa. Christopher Lund has pointed out to me in a personal communication that the two works bear a number of similarities that have escaped notice.

12 Bataillon believed that Lope took his information from Octavio Sapiencia's Nuevo tratado de Turquía (Novelas 205). Lope may well have been familiar with Sapiencia's work, but he takes entire sentences, such as this one, verbatim from Botero: "Sus vecinos son setecientos mil, las tres partes turcos, las dos cristianos, y el resto judíos" (206).

13 For example, seventeenth-century commentators, such as Pellicer (711) and Salazar Mardones $\left(59^{\mathrm{v}}\right)$ cite Botero's Relazioni to explain Góngora's allusions to the Moluccas.

14 On the functions of descriptive geography, see Cormack. 


\section{Works Cited}

Acosta, Cristóbal. Aromatum \& medicamentorum in Orientali India nascentium. Trans. Carolus Clusius. Antwerp: Plantin, 1593. Botanicus. Web. 8 July 2009.

—. Tractado de las drogas, y medicinas de las Indias Orientales, con sus plantas debuxadas al biuo por Christoual Acosta. Burgos: Martin de Victoria, 1578. Dioscorides Digital. Web. 8 July 2009.

Andaya, Leonard Y. The World of Maluku: Eastern Indonesia in the Early Modern Period. Honolulu: U of Hawaii P, 1993. Print.

Balbuena, Bernardo de. La grandeza mexicana y Compendio apologético en alabanza de la poesía. Ed. Luis Adolfo Domínguez. México: Porrúa, 2001. Print.

Barbuda, Luiz Coelho de. Reyes de Portugal, y empresas militares de lusitanos. Lisbon: Pedro Craesbeeck, 1624. Print.

Barros, João de. Década primeira [-terceira] da Asia. Jorge Rodriguez, 1628. Biblioteca Nacional Digital. Web. 2 December 2013.

—. L'Asia del Sig. Giovanni di Barros [... ] Nuouamente di lingua Portoghese tradotta. Dal S. Alfonso Ulloa. Venice: Valgrisio, 1562. Google Books Search. 15 November 2013.

Binotti, Lucia. Cultural Capital, Language and National Identity in Imperial Spain. Rochester, NY: Tamesis, 2012. Print.

Blackmore, Josiah. Moorings: Portuguese Expansion and the Writing of Africa. Minneapolis: U of Minnesota P, 2009. Print.

Botero, Giovanni. Della ragion di stato, libri dieci, con tre libri delle cause della grandezza e magnificenza delle città. Ferrara: Vittorio Baldini, 1589. Google Books Search. 15 August 2012.

—. Descripción de todas las provincias y reynos del Mundo, sacada de las Relaciones toscanas de Iuan Botero. Trans. Jaume Rebullosa. Barcelona: Gabriel Graells and Giraldo Dotil, 1603. Print.

—. Historia eclesiástica y estado presente de la Religión en todos los reynos de Europa, Asia, y Africa: sacada de las Relaciones Toscanas de Iuan Botero Benes. Barcelona: Hieronymo Margarit, 1610. Print.

—. Relaciones universales del mundo. Trans. Diego Aguilar. Valladolid: Diego Fernández de Córdoba, 1599. Google Books Search. 15 August 2012.

—. Theatro de los mayores príncipes del mundo, y causas de la grandeza de sus Estados: sacado de las Relaciones toscanas de Juan Botero. Trans. Jaume Rebullosa. Barcelona: Sebastian Matevad y Onofre Anglada, 1605. Print.

Bouza, Fernando. Imagen y propaganda: capitulos de historia cultural del reinado de Felipe II. Madrid: Akal, 1998. Print.

Boxer, Charles R. João de Barros, Portuguese Humanist and Historian of Asia. New Delhi: Concept, 1981. Print.

—. The Portuguese Seaborne Empire, 1415-1825. New York: Knopf, 1969. Print.

"War and Trade in the Indian Ocean and the South China Sea, 1600-1650." The Great Circle, Journal of the Australian Association for Maritime History I.2 (1979): 3-17. Rpt. From Lisbon to Goa, 1500-1750: Studies in Portuguese Maritime Enterprise. London : Variorum Reprints, 1984. Print. 
Brotton, Jerry. Trading Territories: Mapping the Early Modern World. Ithaca, NY: Cornell UP, 1998. Print.

Camões, Luís de. Lusiadas de Luis de Camoens, principe de los poetas de España. Ed. Manuel de Faria e Sousa. Madrid: Juan Sánchez, 1639. Microfilm.

Castanheda, Fernão Lopes de. História do Descobrimento e Conquista da Índia pelos portugueses. Ed. Manuel Lopes de Almeida. Porto: Lello, 1979. Print.

Caussin, Nicolas. Símbolos selectos y parábolas históricas del P. Nicolas Causino. Trans. Francisco de la Torre y Sevil. Madrid: Juan García, 1677. Print.

Colin, Francisco. Labor evangelica, ministerios apostolicos de los obreros de la compañia de Jesus, fundacion y progressos de su provincia en las islas filipinas. Madrid: Joseph Fernandez de Buendia, 1663. Print.

Cormack, Lesley B. “'Good Fences Make Good Neighbors': Geography as Self-Definition in Early Modern England." Isis 82 (1991): 639-61. Print.

Costa, Fernando Dores. "Interpreting the Portuguese War of Restoration (1641-1668) in a European Context.” E-journal of Portuguese History 3.1 (2005): 1-14. Web. 15 October 2013.

Cunha, Mafalda Soares da. "El Imperio Portugues en tiempo de Felipe III." La Monarquía de Felipe III. Ed. José Martínez Millán and Maria Antonietta Visceglia. 4 vols. Madrid: Mapfre, 2007-2008. IV: 883-899. Academia.edu. Web. 15 November 2013.

Davidson, Peter. The Universal Baroque. Manchester: Manchester UP, 2007. Print.

Faria e Sousa, Manuel de. Asia portuguesa. Lisbon: Henrique Valente de Oliveira, 1666. Google Books Search. Web. 15 November 2013.

Frade, Florbela Veiga, “A presença portuguesa nas ilhas de Maluco: (1511-1605).” Diss. U de Lisboa, 1999. Academia.edu. Web. 2 October 2013.

Fragoso, Juan. Discurso de las cosas aromaticas, arboles y frutales y de otras muchas medicinas simples que se traen de la India Oriental y que siruen al vso de medicina. 1572. Ed. José Luis Fresquet Febrer. Valencia: U de València, 2002. Print.

García Peres, Domingo. Catálogo razonado biográfico y bibliográfico de los autores portugueses que escribieron en castellano. Madrid: Colegio Nacional de Sordo-mudos y de Ciegos, 1890. Biblioteca Nacional Digital. Web. 2 December 2013.

Goodman, David C. Power and Penury: Government, Technology and Science in Philip II's Spain. Cambridge: Cambridge UP, 1988. Print.

Gunn, Geoffrey C. First Globalization: The Eurasian Exchange, 1500-1800. Lanham, MD: Rowman \& Littlefield, 2003. Print.

Headley, John M. "Geography and Empire in the Late Renaissance: Botero's Assignment, Western Universalism, and the Civilizing Process." Renaissance Quarterly 53.4 (2000): 1119-55. Print.

Jameson, A.K. “The Sources of Lope de Vega's Erudition." Hispanic Review 5.2 (1937): 124-39. Print.

Lach, Donald F. and Edwin J. Van Kley. Asia in the Making of Europe. 3 vols. Chicago: U of Chicago P, 1965-1993. Print.

Lobato, Manuel. Política e comércio dos portugueses na Insulíndia. Malaca e as Molucas de 1575 a 1605. Macau: Instituto Português do Oriente, 1999. Print. 
Macedo, António de Sousa de. Flores de España, excelencias de Portugal. Lisbon: Jorge Rodrigues, 1631. Print.

Marcos de Dios, Ángel 2010. "Castilian and Portuguese in the Sixteenth Century." A Comparative History of Literatures in the Iberian Peninsula. Ed. Fernando Cabo Aseguinolaza, et al. Philadelphia: John Benjamins, 2010. 413-28. Print.

Martínez Almoyna, Julio, and Antero Vieira de Lemos. La lengua española en la literatura portuguesa. Madrid: IMNASA, 1968. Print.

Maximilian of Transylvania. "Relación de cómo y por quién y en qué tiempo fueron descubiertas y halladas las islas Malucas." Coleccion de los viajes y descubrimientos que hicieron por mar los españoles desde fines del siglo XV. Ed. Martín Fernández de Navarrete. 5 vols. Madrid: Imprenta Real, 1825-1837. IV: 249-84. Google Books Search. Web. 28 August 2013.

Nicolopulous, James. The Poetics of Empire in the Indies: Prophecy and Imitation in La Araucana and Os Lusíadas. University Park, PA: Pennsylvania State UP, 2000. Print.

Nocentelli, Carmen. Empires of Love: Europe, Asia, and the Making of Early Modern Identity. Philadelphia: U of Pensylvania P, 2013. Print.

Ogilvie, Brian. The Science of Describing: Natural History in Renaissance Europe. Chicago: $U$ of Chicago P, 2008. Print.

Orta, Garcia da. Colóquios dos simples e drogas da Índia. Ed. Conde de Ficalho. 2 vols. Lisboa: Imprensa Nacional, 1892. Google Books Search. Web. 6 April 2011.

Padrón, Ricardo. "A Sea of Denial: The Early Modern Spanish Invention of the Pacific Rim." Hispanic Review 77 (2009): 1-27. Print.

—. "The Blood of Martyrs Is the Seed of the Monarchy: Empire, Utopia, and the Faith in Lope's Triunfo de la fee." Journal of Medieval and Early Modern Studies 36:3 (2006): 517-37. Print.

Pardo, Osvaldo F. "Giovanni Botero and Bernardo de Balbuena: Art and Economy in La grandeza mexicana." Journal of Latin American Cultural Studies 10:1 (2001): 103-17. Print.

Pellicer y Ossau, José. Lecciones solemnes a las obras de don Luis de Gongora y Argote. Madrid: Imprenta del Reino, 1630. Print.

Pigafetta, Antonio. Magellan's voyage around the world [... The original text of the Ambrosian $m s$. Ed. and trans. James Alexander Robertson. 3 vols. Cleveland, OH: Arthur H. Clark, 1906. Print.

Portuondo, María M. Secret Science: Spanish Cosmography and the New World. Chicago: U of Chicago P, 2009. Print.

Rebello, Gabriel. "Informação das cousas de Maluco." Collecção de noticias para a historia e geografia das nações ultramarinas. 7 vols. Lisbon: Academia das Ciências de Lisboa, 1812-56. Print.

Rebullosa, Jaime. Relacion de las grandes fiestas que en esta ciudad de Barcelona se han echo à la canonizacion de su hijo San Ramon de Peñafort. Barcelona: Iayme Cendrat, 1601. Print.

Salazar Mardones, Cristobal. Ilustración y defensa de la fábula de Piramo y Tisbe. Madrid: Imprenta Real, 1636. Print.

Sardinha, Francisco de Morais. O Parnaso de Vila Viçosa. Ed. Christopher Lund. Rio de Janeiro: H.P. Comunicação, 2003. Print.

Sayas Rabanera y Ortubia, Francisco Diego. Anales de Aragón desde el año de MDXX del nacimiento de nuestro Redemptor hasta el de MDXXV. Zaragoza: Herederos de P. la Naja, 1666. Print. 
Sheehan, Kevin J. "Iberian Asia: The Strategies of Spanish and Portuguese Empire Building, 1540-1700." Diss. U of California, Berkeley, 2008. Print.

"Tratado de las Yslas de los Malucos y de los costumbres de los indios y de todolo demás." Documentação para a História das Missões do Padroado Português do Oriente. Ed. Basílio de Sá. 6 vols. Lisbon, IICT-CEHCA, 1988. VI: 3-160. Print.

Valladares, Rafael. Castilla y Portugal en Asia, 1580-1680: declive imperial y adaptación. Leuven: Leuven UP, 2001. Print.

—_ "Olivares y Oriente: La Unión de Armas en Asia, 1622-1642." Imperios y naciones en el Pacífico. Ed. María Dolores Elizalde Pérez-Grueso, José Maria Fradera Barceló, and Luis Alonso Álvarez. 2 vols. Madrid: CSIC. I: 73-80. Print.

—_ "Portugal hispánico: siglos XVI-XVII." Hispania: Revista Española de Historia 64.216 (2004): 9-12. Print.

__ "Portugal y el fin de la hegemonía hispánica." Hispania: Revista Española de Historia 56.193 (1996): 517-39. Print.

Varela Bueno, Consuelo. "Problemas de frontera en el Maluco." A Uniâo Ibérica e o Mundo Atlântico. Ed. Maria da Graça Mateus Ventura. Lisbon: Colibri, 1997. 341-53. Print.

Vega Carpio, Lope de. Jerusalén conquistada: epopeya trágica. Ed. Joaquín de Entrambasaguas. 3 vols. Madrid: CSIC, 1951-1954. Print.

—. Laurel de Apolo. Ed. Christian Giaffreda. Florence: Alinea, 2002. Print.

—. Novelas a Marcia Leonarda. Ed. Antonio Carreño. Madrid: Cátedra, 2002. Print.

- Obras poéticas. Ed. José Manuel Blecua. Barcelona: Planeta, 1983. Print.

Wright, Elizabeth R. Pilgrimage to Patronage: Lope de Vega and the Court of Philip III, 15981621. Lewisburg, PA: Bucknell UP, 2001. Print.

John Slater is Associate Professor in the Department of Spanish and Portuguese at the University of California, Davis. His research examines the early modern textual genres that represent human beings' experience of the natural world, from natural history to religious drama. In addition to numerous articles, he is the author of Todos son hojas: Literatura e historia natural en el barroco español (CSIC: 2010) and is completing a second book on the politics of natural history in early modern Spain titled, Momentary Monuments: The Vegetable Kingdom and the Reign of the Spanish Hapsburgs. 